\title{
Guillain-Barré syndrome
}

\author{
Ario Mirian MD MSc, Michael W. Nicolle MD DPhil, Adrian Budhram MD
}

Cite as: CMAJ 2021 March 15;193:E378. doi: 10.1503/cmaj.202710

\section{Guillain-Barré syndrome (GBS) is the most frequent cause of \\ 1 subacute neuromuscular weakness in North America The median incidence of GBS is about 1 per 100000 person-years, with higher rates in older people (a 20\% increase in the average GBS rate for every 10 -year increase in age) and males. ${ }^{1}$ Infections can trigger GBS (e.g., including those caused by Campylobacter jejuni and influenza virus). However, a large retrospective study published in 2013 found no increased risk of GBS after vaccination. ${ }^{2}$}

2 Guillain-Barré syndrome usually presents with symmetric
ascending weakness and hyporeflexia Weakness usually begins in the lower extremities. ${ }^{3}$ In primary care, patients most commonly present with acroparesthesias followed by subacute ( $4 \mathrm{wk}$ ), symmetric, flaccid weakness with hyporeflexia (Appendix 1, available at www.cmaj.ca/lookup/doi/10.1503/cmaj.202710/tab-related-content). Referral to the emergency department with consideration of inpatient admission to monitor for progressive weakness, respiratory failure and dysautonomia is suggested.

Cerebrospinal fluid (CSF) should be collected on presentation

to exclude mimics before immunomodulatory therapy

Pleocytosis in CSF is a red flag against diagnosing GBS and may signify an infectious mimic such as Lyme disease, HIV, enterovirus or West Nile virus. ${ }^{3}$ Elevated CSF protein with a normal white blood cell count (albuminocytological dissociation) occurs in $50 \%-70 \%$ of cases of GBS in the first week of disease. ${ }^{3}$

The American Academy of Neurology Quality Standards Subcommittee guideline, which was supported by randomized controlled trials, recommended IVIG or PLEX for nonambulatory patients within 2 and 4 weeks of onset, respectively (Level A). ${ }^{4}$ Both are equally effective at improving disability after 4 weeks. ${ }^{4}$ Corticosteroids are not recommended. ${ }^{4}$

\section{Nearly one-third of patients will require mechanical} ventilation, but the long-term prognosis is usually favourable Mechanical ventilation is required for almost $30 \%$ of patients with GBS and is associated with mortality of $5 \%-12 \%$, slower recovery and residual disability. ${ }^{5}$ Recovery begins after clinical nadir at 2-4 weeks, and about $83 \%$ of patients can walk independently at 6 months. ${ }^{5}$ Persistent symptoms may include weakness in the legs, pain and fatigue.

\section{References}

1. Sejvar JJ, Baughman AL, Wise M, et al. Population incidence of Guillain-Barré syndrome: a systematic review and metaanalysis. Neuroepidemiology 2011;36:123-33.

2. Baxter R, Bakshi N, Fireman B, et al. Lack of association of Guillain-Barré syndrome with vaccinations. Clin Infect Dis 2013;57:197-204.

3. Leonhard SE, Mandarakas MR, Gondim FAA, et al. Diagnosis and management of Guillain-Barré syndrome in ten steps. Nat Rev Neurol 2019;15:671-83.

4. Hughes RA, Wijdicks EF, Barohn R, et al.; Quality Standards Subcommittee of the American Academy of Neurology. Practice parameter: immunotherapy for Guillain-Barré syndrome: report of the Quality Standards Subcommittee of the American Academy of Neurology. Neurology 2003;23:736-40.

5. van den Berg B, Storm EF, Garssen MJP, et al. Clinical outcome of Guillain-Barré syndrome after prolonged mechanical ventilation. J Neurol Neurosurg Psychiatry 2018;89:949-54.

\section{Competing interests: None declared.}

This article has been peer reviewed.

Affiliation: Department of Clinical Neurological Sciences, London Health Sciences Centre, London, Ont.

Content licence: This is an Open Access article distributed in accordance with the terms of the Creative Commons Attribution (CC BY-NC-ND 4.0) licence, which permits use, distribution and reproduction in any medium, provided that the original publication is properly cited, the use is noncommercial (i.e., research or educational use), and no modifications or adaptations are made. See: https://creativecommons. org/licenses/by-nc-nd/4.0/

Correspondence to: Ario Mirian, ario.mirian@lhsc.on.ca

CMAJ invites submissions to "Five things to know about ..." Submit manuscripts online at http://mc. manuscriptcentral.com/cmaj 